\title{
Value for money? Fraud in the property market
}

Received (in revised form): 20th February, 2007

\section{Sophie Stallworthy LLB, BA}

is a solicitor within Watson Burton LLP's Commercial Fraud Department. She specialises in acting for companies/ public bodies that have been the victim of fraud. She has provided advice and assistance on a variety of fraud claims, including but not limited to expenses/account frauds, high-value frauds perpetrated against the NHS, and long-term frauds.

Correspondence: Sophie Stallworthy, Watson Burton LLP, 1 St James' Gate, Newcastle upon Tyne NE99 1YQ, UK; Tel: 01912444317 E-mail: sophie.stallworthy@watsonburton.com

\section{Abstract}

This paper considers the predominant forms of fraud encountered in the property/lending industry, and the avenues for recovery available to the victims of fraud once it has been perpetrated.

Journal of Building Appraisal (2007) 3,21-28. doi:10.1057/palgrave.jba.2950062

\section{Keywords:}

mortgage fraud, valuation fraud, criminal prosecution, civil prosecution, tort of deceit

\section{INTRODUCTION}

In the 1980s the British housing market experienced a boom of high house prices and even higher borrowing. By the end of the decade (and into the early 1990s), however, the thriving market was thrown into recession. Homeowners and lenders alike found themselves facing the consequences of negative equity as a result of the overvalued house prices and the depressed housing market. Out of the housing market collapse came revelations of negligent practices and frauds perpetrated by buyers, valuers, and other property professionals.

Reminiscent of the 1980s property scandals, in March 2006 the Cheshire Building Society announced that a $£ 10 \mathrm{~m}$ provision had to be incorporated into its accounts following the discovery of a suspected external fraud concerning various commercial property loans. The alleged fraud was subsequently described in the press as the overvaluation of loans allegedly carried out by a commercial valuer. The Serious Fraud Office is investigating the alleged fraud and has carried out raids on various properties alleged to be involved in the fraud. While the Cheshire Building Society has stressed the isolation of this incident of alleged fraud, it is a timely reminder of fraud in the property market.

By understanding the nature of fraud within the property industry professionals are better placed to ensure that industry standards are upheld. In general terms, a fraud is where a person or persons deceitfully obtains an advantage or benefit or causes loss to another. While this may seem straightforward, the fraud moniker is one that is applied to a multitude of diversely different dishonest acts. It is, therefore, important to consider the various types of fraud encountered in the property industry.

\section{TYPES OF FRAUD}

Frauds perpetrated in the property loan industry are many and varied, with fraudsters always looking for an opportunity for a vehicle for fraud. The six predominantly 
encountered frauds, as considered by the Council of Mortgage Lenders and Stuart Gronow are:

(a) Valuation frauds;

(b) Applicant status fraud;

(c) Resale fraud;

(d) Introducers and applicants colluding;

(e) Frauds involving professionals; and

(f) Insider fraud.

Each of these frauds are considered in turn below.

\section{VALUATION FRAUDS}

\section{Background}

Valuation acts as a tool for lenders, vendors, and purchasers alike to ensure that the value of a property is as represented. For a lender, valuation provides an opportunity to assess the risk of the potential mortgage offer. Therefore, the lender needs to be provided with an accurate guide as to the market value of the property. Through this the lender is, or ought to be, able to determine the level of loan that it is commercially viable to offer a borrower. The lender must be confident that the property offers adequate security for the size of the loan advanced. For the vendor and purchaser, a valuation provides confirmation that they are buying or selling a property at an appropriate price.

An independent valuation is aimed at preventing the misrepresentation of the value of the property by any interested party. Owing to the important role which valuation plays in the property industry, valuation fraud provides all parties with the greatest potential for loss.

\section{Varieties of valuation fraud}

The main variants of valuation fraud are overvaluation, undervaluation, and forged valuation.

\section{Overvaluation}

By having their property overvalued, the borrower is able to obtain a higher mortgage. The surplus funds obtained from the higher mortgage will then be retained by the borrower. Overvaluation may either be with the collusion of the valuer, in which case the valuer may receive a share of the advanced sum, or the valuer may be an unwitting accomplice.

\section{Case study}

In the case of Preferred Mortgages Ltd v Countrywide Surveyors Ltd (Ch D (Edward Bartley Jones QC) 25/7/2005), the valuer's assessment of the subject property was affected by the careful presentation of the property by the suspected fraudster.

\section{The facts}

The case concerned a suspected mortgage fraud perpetrated against Preferred Mortgages Ltd ('PML') by the purchaser of a partially converted chapel in Norfolk. In this case, PML was approached by Mr Pierre Wilson for the provision of a loan to purchase the property. The property had been purchased in November 1991 by Mr Peter Wilson who intended to re-furbish the Chapel and sell it for profit. He failed in his plan and was made bankrupt with the property being transferred by the Official Receiver in January 
1997 to a Mr Paul Strickland. In October $1998 \mathrm{Mr}$ Pierre Wilson (of the same address as Mr Strickland) submitted a loan application form to PML. In or around the same time, Mr Strickland (or another person) contacted a local estate agent to market the property. In November 1998, a Mr Wilson informed the estate agency that he was interested in purchasing the property having viewed it without any appointment. Thereafter, in April 1999, Mr Strickland rang the estate agent and withdrew the property from the market.

The property was then presented to PML by Mr Pierre Wilson as a bona fide purchase from Mr Strickland in the sum of $£ 65,000.00$. In November 1998, Countrywide Surveyors Ltd ('CSL') were instructed by PML to value the property. CSL's valuer visited the property in the same month and conducted his valuation. The property had been fitted out and was carefully presented to the valuer to look as attractive as possible. This careful presentation assisted in concealing that there was no electricity, water, or foul drainage in the property. Mr Wilson ceased making mortgage payments in July 1999, the property was repossessed in September 2000, and the property was sold at a loss in May 2002 following substantial refurbishment work.

\section{Outcome}

PML sought to recover damages from CSL alleging that the valuation report was negligently prepared in breach of the duties which CSL owed to PML both in contract in tort. It was held that the valuers methodology had been careful and competent, and PML failed to establish breach of duty by the valuer.

\section{Comment}

This case, in which mortgage fraud was suspected by the Court, but not proven, highlights the difficulties valuers face if fraudsters are intent on committing fraud. Valuers must not be deceived by artificial attempts to present a property in a certain light, or they may face being unwittingly involved in fraudulent schemes, legal action, and damage to their professional reputation.

\section{Undervaluation}

This type of valuation fraud assists a fraudster at an earlier stage in the property purchasing chain. Often arranged by the estate agent, the price is fixed before the purchaser (acting in collusion with the agent) is introduced to the vendor. Following the completion of the first sale, the property is then re-marketed and sold at its proper market valuation.

\section{Case study}

Masood Asif v City (Europe) Ltd \& 8 ORS (Ch D (Peter Smith J) 25/6/2002) considered the prospect of establishing that a valuer had either fraudulently conspired with others to undervalue properties or that he had been negligent in relation to the valuations that he had given so as to be in breach of his duty of care to the Claimant. The case draws attention to potential valuing frauds valuers may be drawn into.

\section{Facts}

Masood Asif's ('MA') company was the owner of a large number of properties that it had charged to the first defendant ('D1') as security for borrowings. MA had guaranteed the company's indebtedness to D1 and to the company's bank. In due course, D1 obtained charging orders over the properties and obtained orders for their sale. MA's case was that D1 had engaged the fourth defendant ('D4'), a valuer, deliberately to undervalue the 
properties as part of a fraudulent conspiracy whereby the properties would be sold at those valuations to the sixth to ninth defendants, who would subsequently reap the benefit of the true value of the properties. The fifth defendant ('D5') was D4's employer and was joined in the proceedings solely on the basis that it was vicariously liable for the actions of D4. On this application, D4 and D5 contended that: (i) there was no evidence that D4 had been one of the conspirators or that he had provided fraudulent valuations; and (ii) even if he had been negligent in his valuations, D4 had been providing valuation evidence to D1 only, and had owed no duty to C.

\section{Outcome}

It was held by the Court that the extent to which the D4's valuations appeared to undervalue the properties, coupled with evidence about his connections with the other defendants, raised a prima facie case of fraud by $\mathrm{D} 4$ to go to trial. The knowledge was arguably sufficient to impose a duty of care upon D4 for the benefit of MA.

\section{Forged valuations}

A forged valuation is useful to either the vendor or the purchaser intent on fraud. A vendor may produce a forged valuation to defraud a purchaser as to the true value of their property. Alternatively, a forged valuation will assist a purchaser in defrauding the lender.

\section{Other valuation considerations}

Valuation fraud is, unfortunately, a difficult fraud to detect until loss has been caused. Lenders and other professionals involved in conveyancing (such as solicitors) are unlikely to be aware of errors or falsities in a valuation report until such time as loss has been suffered and the valuation report is scrutinised.

The existence of valuation fraud is often concealed through the ambit of professional negligence, unless a clear connection can be demonstrated between the valuer and person instigating the fraud. There are many reported cases of purportedly negligent valuations by valuers, which have been pursued through a professional negligence route. It is perhaps for this reason that there are numerous professional negligence cases, which appear to verge on the fraudulent, but are pursued instead through professional negligence channels.

\section{APPLICANT STATUS FRAUD}

Applicant status fraud covers a range of fraudulent acts connected to falsifying the borrower's financial position on mortgage applications. Common examples are the borrower:

(a) Detailing a false income on the application form;

(b) Falsifying other personal details on the application form;

(c) Providing a false work reference; and

(d) Concealing his/her credit rating through omitting such information as County Court judgments, previous evictions, bankruptcy, or other existing mortgages or loans. (Competition Commission, 1994).

Often an applicant committing an applicant status fraud will have to collude with a third party, such as his employer, or his mortgage broker, to provide false information.

It should be noted that with applicant status frauds, if the valuation of the property is correct then the person who will suffer the ill effects of the fraud is likely to be the borrower unable to meet repayments. If the valuation is accurate, the lender should upon repossession and resale of the property, recover, in the main, the monies lent. 
Out of the housing crash of the 1980s, The Council of Mortgage Lenders in conjunction with credit agencies Experian and Equifax, established a Possessions Register in August 1991. Through this register, lenders are meant to share information as to persons whose properties have been repossessed. Industry information sharing such as the Possession Register is an important step to take to curb applicant status fraud. Information sharing is, however, only as good as the information exchanged. A sophisticated fraudster is likely to be able to utilise new and false information to circumvent information sharing.

\section{RESALE FRAUDS/LETTING FRAUD}

This fraud, a variant of the applicant status fraud, occurs where the fraudster applies for loans in different names on numerous properties in order to make a rapid sale at a profit. Alternatively, they may seek to rent their properties and use the rental income to repay the loans (Gronow, 1991).

\section{INTRODUCERS AND APPLICANTS COLLUDING}

A fraud that is perhaps a further variant of applicant status fraud is the submission of false mortgage applications encouraged and instigated by a borrower's mortgage broker. With brokers often benefiting from fees for their advice, processing applications and providing references together with commissions from lenders in relation to loans processed through them, the temptation for brokers to encourage fraud can be strong. As the Council of Mortgage Lenders have identified, broker instigated fraud may take the form of advising a borrower to falsify their income details, show then how to falsify their income details, providing false references or even forging P60 information (Council of Mortgage Lenders, August 1989).

In February 2004, BBC's 'The Money Programme' broadcast the results of their own investigation into 'self-certification' mortgages. Self-certification is a form of mortgage that allows the applicant to apply for mortgages without providing proof of their income. In the course of their investigation, 'The Money Programme' encountered numerous mortgage brokers encouraging its agent to lie on their mortgage application. While no figures were released as to the prevalence of advisors and brokers encouraging false mortgage applications, it is clear that such practices still continue. Indeed in December 2006 the Financial Services Authority announced the launch of an initiative to work with mortgage lenders to understand and combat mortgage fraud in instances where there is suspected intermediary assistance.

\section{FRAUDS INVOLVING PROFESSIONALS}

Solicitors, licensed conveyancers, and accountants must also be monitored for fraudulent activities. Professionals are often involved in frauds by providing false references for fraudsters, laundering money, and generally providing a false veneer of professionalism.

\section{Case study}

A fraud ring prosecuted by the Serious Fraud Office (SFO) highlights the manner in which fraudulent professionals are able to participate in property frauds.

\section{Facts}

In November 2004, the SFO successfully prosecuted six fraudsters (Noel Ward, Raymond Brown, Ian Colphon, Tracey Ryder, and Howard Clayton) involved in a mortgage lending 
fraud. This group of fraudsters included a conveyancing clerk, a mortgage broker, and a chartered accountant. A solicitor, John Fitzpatrick was also thought to be involved in the fraud, but is believed to have fled the jurisdiction prior to trial.

The fraud was perpetrated by the fraudsters submitting mortgage applications for advances where the price detailed on the applications was higher than the actual purchase prices. In support of their false application the fraudsters produced false documents, forged documents, and other misleading information. Through their activities, the fraudsters obtained advances from various banks in excess of $£ 1 \mathrm{~m}$. The proceeds of the frauds committed over five properties were laundered through a solicitor's firm in August 2000 and June 2001.

\section{INSIDER FRAUD}

Lenders should also be aware of the threat of fraud from within their organisations. Insider fraud may involve a staff member colluding with borrowers or even involve staff obtaining a mortgage benefit for themselves.

The Bank of Scotland has been a high profile victim of internal fraud following the discovery of a $£ 21 \mathrm{~m}$ loan fraud perpetrated by bank manager Donald MacKenzie. While the fraud did not necessarily relate to mortgage loans, it highlights the importance of stringent internal fraud policies.

\section{A FRAUD UNCOVERED - PUNISHMENT VS RECOVERY}

Once a fraud is discovered, the victim is confronted with certain choices as to how to deal with the losses suffered. The decisions made are often coloured by two desires. First, to punish the fraudster and secondly to recover the losses.

The two main avenues for prosecution available to a victim of fraud are criminal and civil prosecution. These avenues are not mutually exclusive and provide victims with the tools to both punish the fraudster and recover any monies lost.

\section{COMMON LAW REMEDIES}

If a person has been the victim of fraud, recovery against the fraudster may be possible through tort or contract. Civil prosecution can be a useful tool of recovery against fraudsters. As the matter is pursued by the victim (through their solicitors), the timescales and resources are able to be better managed than criminal prosecution.

Civil claims also provide greater flexibility as to who is pursued, how the claim is progressed, and how enforcement of a judgment is achieved.

Claims in the civil courts are also tried at a lower evidential level, so that a claimant must only prove their claim on the balance of probabilities instead of beyond reasonable doubt. Where fraud is alleged, the burden of proof should be, however, considered in light of Re H and Others (Minors)(Sexual Abuse: Standard of Proof) [1996] AC 563. At 586 the Court held that 'the more serious the allegation the less likely it is that the event occurred and, hence, the stronger should be the evidence before the court concludes that the allegation is established on the balance of probability. Fraud is usually less likely than negligence'. This dicta highlights the scrutiny courts will apply to allegations of fraud.

It should also be noted that generally to bring a tortious or contractual claim in the civil courts, the claimant has six years from the date of the fraud to issue proceedings. Pursuant to s32 of the Limitation Act 1980, the six-year limitation period, however, shall not begin to run until the claimant has discovered the fraud or could with reasonable diligence have discovered it. 


\section{The tort of deceit}

The main common law cause of action which could be used against property fraudster, such as a fraudulent valuer, is the tort of deceit. For a valuer who makes a valuation which is fraudulent (namely one which he knows to be false or which he makes recklessly without regard to whether it is true or false) with the intention that it should be acted upon, is liable to an action of deceit by any person who was intending to act upon that valuation and who acts upon it to their detriment.

The tort of deceit was first established in Palsey $v$ Freeman (1789) 3 T.R. 51. where it was held that $\mathrm{A}$ is liable in tort to $\mathrm{B}$ if he knowingly or recklessly makes a false statement to $\mathrm{B}$ with intent that it shall be acted upon by B, who does act upon it and thereby suffers damage. The tort was then developed in the leading case of Derry v Peek (1889) 14 App. Cas 337. In this case, the House of Lords held that a false statement made carelessly and without reasonable ground for believing it to be true could not be fraud. For liability in deceit the defendant must make the statement with knowledge of its falsity or at least be reckless as to whether it was true or false.

In Bradford Building Society v Borders [1941] 2 All ER 205, Lord Maugham clarified the established dicta identifying the elements required for an action for deceit namely:

(i) a representation of fact;

(ii) the making of it with knowledge that it is false;

(iii) the making of it with the intention that it should be acted upon by the victim, or by a class of persons which will include the victim, in the manner which resulted in the damage to him; and

(iv) reliance on the representation by the victim resulting in damage.

The requirement for knowledge that the representation is or may be false distinguishes deceit from the tortious action for negligent misstatement

\section{CRIMINAL SANCTIONS - THE NEW OFFENCE OF FRAUD}

Criminal sanctions provide the victim of fraud with an opportunity to see their fraudster punished whether by imprisonment or fine for their crime. Criminal proceedings do, however, suffer from an under-resourced and over-worked state apparatus which may not have the capability to fully pursue the fraudster. Criminal proceedings are also unlikely to recover monies stolen through the fraud. Nevertheless, it is an important tool of retribution for victims, which can be run alongside civil proceedings.

Until the Fraud Act 2006, fraud was undefined in statute. Activities considered fraudulent were covered by deception offences contained in the Theft Acts 1968-1996. These offences were considered difficult to prosecute particularly with increasing technological advances. There was therefore increasing pressure on the legislature to reform fraud law.

From this pressure the Fraud Act 2006 was born. Coming into force on 15th January, 2007 the Act repeals and replaces the eight deception offences in the Theft Acts 1968 1996. It also introduces a general offence of fraud and other fraud offences, which can be used against fraudsters.

The new general offence of fraud, introduced by Section 1 of the Act, has three main prongs:

(a) Fraud by false representation (Section 2);

(b) Fraud by failing to disclose information (Section 3); and

(c) Fraud by abuse of position (Section 4). 
There are two vital requirements that must be fulfilled for any of the above limbs to be shown. First, the behaviour of the defendant must be dishonest. Dishonesty is established through the two-stage test held in $R v$ Ghosh [1982] QB 1053:

1. the defendant was dishonest by the ordinary standards of reasonable and honest people; and

2. realised what $\mathrm{s} / \mathrm{he}$ was doing was dishonest by such standards.

Secondly, it must also be the defendant's intention to make a gain or cause a loss to another. There will not, however, be any need to prove that a gain or loss has been made, or that any victim was deceived by the defendant's behaviour. Loss and gain are broadly defined in Section 5 as being money or property.

The new offences have proven necessary to assist the legislators in coping with new unlawful acts emerging due to technological advances and greater use of the internet and online resources.

Section 4 of the Act is intended at catching those who take advantage of their position, where they are expected to safeguard another's financial interest. The section covers both acts and omissions. Yet again, the section is drafted in broad terms, 'Position' and 'abuse', key terms in the section, are left undefined. This creates a lack of legal certainty and legislation that is in many ways open to the interpretation of the reader.

\section{CONCLUSION}

Fraud in the property lending industry is a very real concern, with fraudsters regularly perpetrating established frauds against lenders and third parties. Unfortunately, the frauds associated with lending are often only identified once it is too late. The industry needs to ensure that practices are developed to identify frauds at an earlier stage through more stringent internal policies, the encouragement of truly independent valuers, and information sharing within the industry. The industry must also be aware that once a fraud is discovered, victims have many options of recovery available to them, and that the civil and criminal courts can work together against the fraudster.

\section{Disclaimer}

This paper is designed to alert professionals. It cannot, nor is it designed to replace the need for advice on specific issues or circumstance.

\section{References}

Bradford Building Society v Borders [1941] 2 All ER 205.

Competition Commission (1994) 'The supply of residential mortgage valuations: A report on the supply in the UK of residential mortgage valuations', www.competition-commission.org.uk/rep_pub/reports/1994/353resmortgage. htm\#full.

Derry v Peek (1889) 14 App. Cas 337.

Fraud Act 2006. In force 15 January 2007.

Gronow, S. (1991) 'Building society mortgage valuation fraud', Journal of Property Valuation and Investment, 10, 701.

Preferred Mortgages Ltd v Countrywide Surveyors Ltd (Ch D (Edward Bartley Jones QC) 25/7/2005).

Masood Asif v City (Europe) Ltd \& 8 ORS (Ch D (Peter Smith J) 25/6/2002).

Palsey v Freeman (1789) 3T.R. 51.

$R v$ Ghosh [1982] QB 1053.

Re H and Others (Minors)(Sexual Abuse: Standard of Proof) [1996] AC 563. 